THE INTERNATIONAL

REVIEW OF RESEARCH IN

OPEN AND DISTANCE LEARNING

\title{
Book Review - Web 2.0-Based E-Learning: Applying Social Informatics to Tertiary Teaching
}

Authors: Mark J. W. Lee and Catherine McLoughlin (2011) Hershey, PA: IGI Global. 483 pp.

ISBN 978-1-60566-294-7

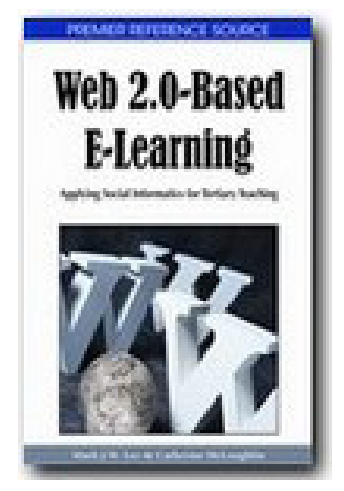

Reviewer: Juan Leon, Thomas Jefferson University School of Population Health, USA

This timely collection of articles will help teachers in higher education explore the implications and applications of social software tools for web-enabled courses and programs. The collection is particularly valuable for its broad scope, including chapters ranging from podcasting to the design of personal learning environments, and for its success in complementing theoretical perspectives with detailed accounts of evidence-based practice. The early chapters in this collection address contemporary learning theories on web-based instruction, prompting the reader to reflect on the type of paradigm shift Web 2.0 may represent for teaching and learning. These chapters are followed by a series of case studies that comprise the largest section of the book. The case studies provide numerous examples of best practices and action research. The final section of Web 2.o-Based E-Learning looks to future directions in web-based education and takes into account Web 2.o's potential impact on professional development plans for academic staff.

The complementarity of the theoretical and applied aspects of the book's contents emerges in part through the shared themes of participation, personalization, and productivity, the "three P's," articulated by the book's editors in their chapter on Pedagogy 2.o. Mark Lee and Catherine McLoughlin, faculty at the schools of education at Charles Sturt and Australian Catholic University, respectively, draw upon their extensive research in pedagogical uses of Web 2.o technologies and learner-generated content to propose a pedagogical framework responsive to the needs of today's learners and the affordances of social software tools promoting networked communities of learning. The three P's framework promotes learner agency and choice, and it foregrounds learner-created content. Key elements of participa- 
tion include collaboration and community. Personalization encompasses both customization of content and learner self-regulation and management. Productivity extends to the learners' contributions to knowledge. The elements of Pedagogy 2.o (I've presented an abbreviated list here) derive from a clear and compelling vision of what is essential in education:

True educational value arguably lies in the enablement of personalized learning experiences that empower students to take charge of their learning journeys, collaborating with peers and experts and drawing on multiple sources both within and outside of the formal learning environment to produce their own ideas, content, and resources. (p. 50)

This statement about true educational value-one could almost call it an ethic or credounderlies the three P's framework. It also voices more general themes that integrate the theoretical and applied content throughout the book.

The first section of Web 2.O-Based E-Learning traces the evolution of computer-mediated communication through to our present-day emergence into a new, collaborative pedagogical ecology, a present-day shift that has implications for the design of instructional materials, training in the workplace, and the measurement of learning outcomes. This section concludes by considering the newly prominent role of learner-generated content and forward-looking experiments in the construction of personal learning environments.

The case studies of the second section of the book enrich the more theoretical discussion and pedagogical models of the first section in a number of ways. Readers may find it illuminating, for example, to reflect back on the chapter about personal learning environments having read the insightful discussion of personal knowledge management (PKM) presented in chapter six. The analysis of PKM competencies ("Personal Knowledge Management Skills in Web 2.0-Based Learning") reminds us that personal learning environments can't build themselves. Students will need deliberate guidance as they develop the personal knowledge management competencies that will enable them to construct these environments for themselves. Other topics in this application-oriented section of the book include the use of Web 2.0 tools for creating authentic learning environments, multiple uses for blogs and wikis, and the distinctive affordance of mobile technologies.

Of special value is an idea-inspiring, practical how-to chapter on podcasting. The chapter's literature review highlights innovative podcasting practices around the globe and lists the unique benefits of podcasting for distance learning. Four categories of benefits are identified: increasing motivation, improving outcomes, extending access, and building community. Of special value to lesson designers will be the figure depicting 10 dimensions of planning for educational podcasting (p. 237). Also notable is the chapter on using Web 2.0 tools to support libraries, student services, and other non-teaching areas that contribute to learning and student satisfaction, an often-overlooked part of Web 2.o's potential for 
educational organizations.

The case study section is rounded out with an account of using Facebook to enhance student learning and an important critique of the concept of "digital natives" as applied in education contexts. In addition, two chapters delineate fault lines created by the shifting ground of online learning today. In chapter 14, Henk Huijser and Michael Sankey of the University of Southern Queensland question whether an institutionally controlled and centrally administered learning management system can be reconciled with Web 2.0 functionality and ethos. Secondly, Denise Whitelock of the Open University challenges us to imagine assessment strategies and tools that would more fully align with Web 2.0-based pedagogy, offering several practical approaches for moving us in the right direction. Anyone not already familiar with Bobby Elliott's 10 characteristics of Assessment 2.0 assessment activities, authentic, personalized, negotiated, and more, will find a convenient listing here (p. 325).

The forward viewpoint explicitly adopted for the book's final section draws the authors of these concluding chapters to reflect on how knowledge will be defined, created, and shared in a world transformed by social technologies. Topics include postmodern epistemic learning spaces and the constructive use of metaphors for making sense of a complex and changing educational landscape. A tentative look at what Web 3.0 could entail takes account of the influence of cloud computing, the Semantic Web, and the increasing use of threedimensional imagery, and a sobering chapter contributed by Belinda Tynan and Cameron Barnes of the University of New England, Australia, identifies ways in which traditional institutions and traditional teaching staff must develop if the potential of Web 2.o for learning is to be more fully realized.

The breadth and depth of coverage offered by Web 2.o-Based E-Learning will make it an excellent addition to a reference collection, while the volume's structure will make it a highly readable companion for advanced courses in online education. Readers will come away with a detailed snapshot of the state of the art in adapting social technologies for instructional purposes, and researchers will appreciate the thorough literature reviews that are part of each article as well as the convenient compilation of references placed in the back matter.

Some readers may want to supplement this book in two areas. First, the chapters of $W e b$ 2.o-Based E-Learning are written almost exclusively by English-speaking authors, and the case studies are grounded almost entirely in English-speaking environments. One is left wondering how the three P's of participation, personalization, and productivity may be inflected in other cultural contexts, or how mobile computing in Asia or Africa could be resequencing patterns of the evolution of learning technologies seen elsewhere. Secondly, research in the application of social technologies for tertiary teaching could benefit going forward by taking into account the implications of Web 2.0 tools and values on the producers of courses themselves-course authors. While course authors remain present implicitly in contemporary discussions, today's discussions do little to change the model of the independent, even isolated, course author. We need a "three P's" for faculty developing courses in a Web 2.0 world. A companion volume to Web 2.O-Based E-Learning addressing how 
Web 2.o tools can facilitate the collaborative design and development of courses and learning environments by faculty teams, students, and other contributors would be a welcome start.*

*An example of this kind of renewal of attention for the design/authoring process is MindMeld: Micro-Collaboration Between eLearning Designers and Instructor Experts. Jon D. Aleckson and Penny Ralston-Berg. Madison, WI: Atwood Publishing, 2011. 